\title{
Sustainable Urbanization: Issues and Challenges for Effective Urban Governance in Nigeria
}

\author{
Adesoji David JIBOYE \\ Department of Architecture, Obafemi Awolowo University \\ Ile-Ife, Osun State, Nigeria. \\ Tel: 23-48-0323-23637Ｅ-mail: jiboye.adesoji@gmail.com
}

$\begin{array}{lc}\text { Received: October 9, } 2011 & \text { Accepted: October 27, } 2011 \quad \text { Published: December 1, } 2011 \\ \text { doi:10.5539/jsd.v4n6p211 } & \text { URL: http://dx.doi.org/10.5539/jsd.v4n6p211 }\end{array}$

\begin{abstract}
The pervasiveness and spontaneity of the global Urbanization process has been an issue of concern in recent time; as this essentially constitutes serious challenge to the attainment of sustainable development and effective urban governance. The implications of this developmental challenge in many developing nations, including Nigeria; are diverse socio-economic, cultural and environmental problems. Addressing these urban developmental challenges in Nigeria requires effective and good governance. The main concern of this paper therefore is to examine this developmental issue in order to provide a rationale for good governance in the management and utilization of existing resources for sustainable urban growth in Nigeria. The paper addresses four main areas: the first considers basic issues relating to sustainable development and governance; the second discusses the challenge of urbanization in Nigeria; while the third underscores the need for effective governance in sustainable urbanization. The paper conceives three major policy areas which are relevant to ensuring good governance in Nigeria. In concluding, the paper notes that appropriate policies and strategies critical to the attainment of sustainable development must be put in place in order to preserve our cities and also secure the future well-being of it citizens.
\end{abstract}

Keywords: Urbanization, Sustainability, Development, Urban governance, Challenges, Nigeria

\section{Introduction}

One of the critical issues of concern to most national governments world over is the need to stem the rate of urbanization induced by the incidence of globalization, industrialization and an unprecedented population growth rate in the cities. (Jiboye, 2005; Osasona et al., 2007). This concern has led to several global Summits organized at various level of government, international Agencies including the United Nations. Specifically among such are, the Millennium Development Goals Summits, the 2002 world summit in Johannesburg and the 2005 La-Havana UN sustainable cities documentation of experience programme among several others. In each of these summits, member nations reiterate the need for good and effective governance as a means of achieving sustainable development in the cities. (Oladunjoye, 2005; UN-Habitat, 2007; UNDPI, 2008; Jiboye, 2011a).

In explaining and rationalizing this global developmental issue, a World Bank Report in 2000 and another of the International Monetary Fund in 2006, had indicated that about 66 percent of the world's population lived in the countryside in the early 1950s; however, current estimate by the United Nations has put the world population at 6.572 billion people, of which 3 billion (about 50\%) now live within the urban areas, and by 2030, about 61 percent of the world population is projected to live in the cities; and this growth is expected to occur mainly in developing countries (UN, 2004; UNCHS, 2007; UNFPA, 2007; Daramola \& Ibem, 2011).

While continents like Europe and America have stabilized their population growth and economy to a large extent, most countries in Africa, Asia and Latin America, are still grappling with the challenge of ensuring a decent livelihood to their citizens. Specifically in Africa where there is high rate of overpopulation, congestion, pollution, inadequate shelter, squalor, underdevelopment and increasing incidence of poverty; the rapid urbanization has not produced any appreciable improvement in the national economy and welfare of the citizens. Rather, the uncontrolled and unplanned urbanization has brought about severe socio-economic, cultural and environmental problems. (UNCHS, 2007; Jiboye, 2009; 2011a; Daramola \& Ibem, 2011).

Going by another Report, the United Nation's Habitat had estimated that almost a billion people already live in slum conditions around the world and that slums are growing dramatically within the world's poorest cities, particularly, in Sub-Sahara Africa and Asia (UN-Habitat, 2007). With the increasing population explosions and 
massive rural-urban migration accompanying the urbanization process in the developing countries; global economic integration, increased international trade, capital flows, telecommunication, new waves of technologies, and shifts in the comparative advantage of production continue to play a central role in integrating major urban centers and shaping the spatial organization of the cities (Jiboye, 2005). The reality of this scenario is congestion resulting from overpopulation and proliferation of slums in the cities (Ravalin, 2007; Jiboye, 2009).

In Nigeria, the urbanization process is similar to what obtains in several other developing countries; as the growth and complexity of human settlements and in particular the rate of urbanization has been phenomenal (Ujoh et al., 2010). Considering its 2006 population figure of over 140 million people - the highest in Sub-Saharan Africa (Ajanlekoko, 2001; FRN, 2007; Jiboye, 2011a); available data however shows that the country has been growing at the rate of 5.5 percent annually from 1980 to 1993, and recently, its growth has increased to the rate of 5.8 percent, which has resulted in a total urban population of 62.66 million people (or, 43 percent of the national population). By projection, this proportion is expected to increase to more than 60 percent by 2025 (UN, 2007). Consequently, Nigeria has one of the highest urban growth rates, having cities ranked among the fastest growing in the world. Not only is the country experiencing one of the fastest rates of urbanization in the world, its experience has also been unique in scale, pervasiveness and historical antecedents. This process has resulted in a very dense network of urban centres (Oladunjoye, 2005); thereby constituting a major problem to the urban residents whose quality of life and living conditions have deteriorated considerably (Ajala, 2005; Jiboye, 2009; 2011a). However, it has been established that the degrading condition of the cities' environment in most developing nations affects the socio-economic and national development (Ogunleye, 2005). Therefore, a major developmental challenge facing the nations -particularly those within the developing world, is how to cope with the increasing urbanization and minimize its adverse consequences on the cities' environment as well as the overall wellbeing of the people (Jiboye, 2011b).

Despite efforts at both the local and international levels toward resolving this urban growth problem and ensuring sustainable development, current realities suggest that the goal of achieving sustainability in the country is yet to be realized. Rather than improving, the physical condition of the cities continues to degenerate while investment in urban infrastructure including housing, has failed to keep pace with the growing population (Jiboye, 2009). A major reason attributable for these urban developmental problems in Nigeria is the lack of effective mechanism of governance needed to ensure a rational level of equilibrium between the growing population, the cities environment and existing infrastructure; hence, the increasing poor quality of the living conditions and low livability index of urban areas in Nigeria (Jiboye, 2011b; Daramola \& Ibem, 2011). There is a need for effective mechanism to stimulate progressive urbanization in our cities. This need thus constitutes a critical challenge to urban governance and development in Nigeria.

\subsection{Aim and Objectives of paper}

The aim of this paper is to examine the challenge of urbanization in Nigeria, in order to provide a rationale for good governance towards achieving sustainable development. To achieve this, the paper will address four main objectives: the first considers basic issues relating to sustainable development and governance; the second discusses the challenge of urbanization in Nigeria; while the third underscores the need for effective governance in sustainable urbanization. The paper conceives three major policy areas which are relevant to ensuring good governance in Nigeria. In concluding, the paper notes that appropriate policies and strategies critical to the attainment of sustainable development must be put in place in order to preserve our cities and also secure the future well-being of it citizens.

\subsection{Theoretical Issues}

Basic issues significant to this discussion include; Sustainable development and urban governance.

\subsubsection{Sustainable Development}

The concept of "Sustainable Development" has been in existence even before the turn of the century. It is a socio-ecological process characterized by the fulfillment of human needs while maintaining the quality of the natural environment indefinitely. This concept came into general usage following publication of the 1987 report of the Brundtland Commission - formally, World Commission on Environment and Development. It is this Commission, set up by the United Nations General Assembly that coined the most often-quoted definition of sustainable development which is "development that meets the needs of the present generation without compromising future generations to meet their own needs" (WCED, 1987; Jiboye, 2011c; Daramola \& Ibem, 2011). However, several other definitions have been given to explain this concept; one of such emanated from the National Affordable Housing Agency of Britain, describing it as a means of ensuring a better quality life for everyone, now and for generations to come (NAHA, 2006). It is the process of building our communities so that 
we can live comfortably without consuming all of our resources. This implies, living in a sustainable way by conserving more of the things we all need to share - this is not just about consuming resources, but includes changing our culture to make conservation a way of life (Mediawiki, 2008).

Although, the visions of sustainability vary across regions and circumstances, a broad international agreement has emerged that its goals should be to foster a transition toward development paths that meet human needs while preserving the earth's life support systems and alleviating hunger and poverty - i.e., that which integrate the three pillars of environmental, social and economic sustainability (William et al., 2002). Viewed from another perspective, sustainable development entails the attainment of equilibrium among three contending sub-systems which have economic, socio-cultural and environmental dimensions (Padisson, 2001; Daramola \& Ibem, 2011). In recognition of the pressing environmental and developmental problems facing the world, the 1992 Earth Summit in Rio-de Janeiro, adopted Agenda 21, which produced a global programme of action for sustainable development in the 21st century (UNCHS, 1996; Lawanson, 2005; UN-Habitat, 2007; Oduwaiye, 2009); stating as its primary objective the need to reduce absolute poverty of the world's poor by providing lasting and secure livelihoods that minimize resource depletion, environmental degradation, cultural disruptions and social instability. Thus, Agenda 21 stresses the importance of good governance through effective partnerships among stakeholders in improving social, economic and environmental quality in the urban areas (Jiboye, 2011b; c)

Consequent upon the adoption of Agenda 21, the 2002 World Summit on sustainable development in Johannesburg further espoused the intrinsic link between socio-economic, cultural and environmental development as well as the right of the individual to improved living condition in any given society or nation. Thus, a socially, economically or an environmentally sustainable system should achieve distributional equity, provision of adequate social services including health, education, housing as well as functional and livable environment among many others (Lawanson; 2005; Jiboye, 2011c). Since the Rio Earth Summit in 1992, sustainable development has emerged as a new paradigm of development, integrating economic growth, social development and environmental protection as interdependent and mutually supportive elements of long-term development. Sustainable development thus emphasizes a participatory, multi-stakeholder approach to policy making and implementation, mobilizing public and private resources for development and making use of the knowledge, skills and energy of all social groups concerned with the future of the planet and its people (Desai, 2002; Jiboye \& Omoniyi, 2010).

With regards to "urban growth", sustainable development implies the ability of the urban areas and their regions to continue to function at levels of desired quality of lives by community without limiting the options available to the present and future generations; and resulting to diverse impacts within and outside their boundaries. Nevertheless, the pace and scale of growth in urban areas have outstripped the capacity to maintain acceptable standards of public health, environmental safety, and sustainable economic growth in the less developed nations of Africa, Asia and Latin America (Adedeji, 2005; Daramola \& Ibem, 2011).

\subsubsection{Urban Governance}

McCarney et al. (1995) defined governance as "the relationship between civil society and the state, between rulers and ruled, the government and the governed. According to the definition provided by the United Nations Development Programme (UNDP) in 1997, governance is "the exercise of political, economic and administrative authority in the management of a country's affairs at all levels. It comprises the mechanisms, processes and institutions, through which citizens and groups articulate their interests, exercise their legal rights, meet their obligations and mediate their differences". Aluko (2010) also defines governance as the act or process of governing a nation, state, or legal entity. It is the activity of governing a country, controlling, ruling, managing, regulating, influencing, or directing a place. Governance recognizes that power exists inside and outside the formal authority and institutions of government. Most formulations of governance recognize government, civil society and the private sector as the key actors. At the local level, these groups can be further specified to include: Central Government, state or provincial government (where applicable), local authorities, non-governmental organizations (NGOs), community-based organizations (CBOs), and the private sector. In the urban context, governance is the sum of many ways individuals and institutions plan and manage the common affairs of the city (Adegun, 2011).

Governance is a neutral concept in which the actors, mechanisms, processes and institutions can produce positive or negative results, hence the notion of "good urban governance". As indicated in the UNDP policy document, good governance is a necessary ingredient to achieve equitable and sustainable growth and development. In other to support the implementation of the Habitat Agenda goal of "sustainable human settlements development 
in an urbanizing world", The UN-HABITAT launched the Global Campaign on Urban Governance in 1999. The Campaign's goal is to contribute to the eradication of poverty through improved urban governance. It aims to increase the capacity of local governments and other stakeholders to practice good urban governance and to raise awareness and advocates for good urban governance around the world. The campaign is implemented through four principle strategies: normative debate, advocacy, capacity building and knowledge management. An index was developed to support the Campaign's advocacy and capacity-building strategies. The index has a two-fold purpose: at the global level, the index will be used to demonstrate the importance of good urban governance in achieving broad development objectives, such as the Millennium Development Goals and those in the Habitat Agenda. Organizations such as UN-HABITAT, UNDP and the World Bank have long advocated for increased investments in urban development based on a common argument.

At the UN-Inter-Agency meeting in 2001, five principles of good urban governance were adopted which consisted of effectiveness, equity, participation, accountability and security; and these formed the framework for developing indicators for the Urban Governance Index (UN-HABITAT, 2004). The Agency defines the principles as follows:

- Effectiveness of governance measures efficiency, subsidiarity and strategic vision.

- Equity addresses sustainability, gender equality and intergenerational equity.

- Accountability measures transparency, rule of law and responsiveness.

- Participation includes citizenship, consensus orientation and civic engagement.

- Security addresses conflict resolution, human security and environmental safety.

These principles demonstrate that good urban governance is vital to improving the quality of life in cities. At the global and regional level, the index is expected to facilitate comparison of cities based on the quality of their urban governance. At the local level, the index is expected to catalyze local action to improve the quality of urban governance by developing indicators that respond directly to their unique contexts and needs. Good governance has eight major characteristics. It is participatory, consensus oriented, accountable, transparent, responsive, effective and efficient, equitable and inclusive and follows the rule of law. It assures that corruption is minimized, the views of minorities are taken into account and that the voices of the most vulnerable in society are heard in decision-making. It is also responsive to the present and future needs of society (UNDP, 1997; Jiboye, 2011b). However, a World Bank Research in 2002 had demonstrated that good governance correlates with positive development outcomes. The survey concluded that: "the result of good governance is development which gives priority to the poor, advances the cause of women, sustains the environment, and creates needed opportunities for employment and other livelihood" (UN-HABITAT, 2004; Jiboye, 2011b).

\section{The challenge of urbanization in Nigeria}

Urbanization is a "process of human agglomeration in multi-functional settlement of relatively substantial size" (Mabogunje, 1985). According to Ujoh et al., (2010), it is the process that refers to the growth both in size and numbers of urban centre. This process, as explained by Adesina (2003), has been responsible for transforming towns, cities and metropolitan areas, while at the same time depopulating the rural setting through a process of direct rural-urban migration. Citing Brockerhoff (2000), Adegun (2011) describes the level of urbanization as the share of a country's total population that lives in urban areas. Thus, the extension of the urban environment in terms of territorial coverage and population has remained a common experience all over the world; while the proliferation of urban centre has been phenomenal from the turn of the 20th century (European Environment Agency, 2006; Ujoh et al., 2010). However, urban extension did not take place in the third world cities until after the Second World War when such became European Colonial Settlements. In most part of Africa, even Asia and Latin America, strategic cities along the coast, for many decades represented trade point and gateways for export and import. These cities continuously improved in economic activities through time, and subsequently transformed to industrial cities. Today, urban centre dominates African countries landscape with their attendant opportunities.

The United Nations Fund for Population Activities (UNFPA) during the 1999 World Habitat day confirmed that urban revolution has begun of which Africa and other developing countries would have to face great challenges. The fastest population growth would take place in Africa, and this has continued to grow over the years, from 133 miliion in 1900 to 225 milion in 1950; while there were about 674 million people in 2000 . The population is expected to continue to increase to 1.5 billion in 2030, with the annual growth rate of about 2.1 percent (National Academy of Sciences, 2003; Adegun, 2011). This population rise would take place mostly in the cities. However, the United Nations demographic experts have estimated Africa's annual urban growth rate at about $5.3 \%$ in 1980 
and 3.4\% in 2000. The region's urban population grew from 32 million in 1950 (15 percent of the region's entire population) to 102 million in 1975 and 220 million in 2000 (33 percent of the region's entire population). Current figure as at 2010 indicates that the number of city dwellers on the continent now stands at 321 million (about 40 percent of the region's entire population). This is projected to reach 787 million by 2030 (see Table 1); - thereby crossing the 50 percent urban threshold sometime before 2025 and reaching 53 percent by 2030 , (United Nations, 2002; Adegun, 2011).

Urbanization is not a new phenomenon in Africa, as cities such as Lagos, Kano, Ibadan, Cairo, Johannesburg, Kinshasha and Addis Ababa, have grown to become large metropolitan urban areas. The city of Lagos for instance, has continued to grow in size since the 1960s; its annual growth rate was close to 14 percent during the 1970s, when the massive extent of new construction was exceeded by the influx of migrants attracted by the oil boom. Acknowledged to be the largest city in sub-Saharan Africa, Lagos has become legendary for its congestion and other associated urban problems. Essentially built on poorly drained marshlands, the city commonly has flooding during the rainy season, and there is frequent sewage back-up, especially in the poorer lowland sections. As in other Nigerian cities, there is a constant problem of garbage and waste disposal. Housing construction has boomed but rarely seemed to keep pace with demand. The city's main fame, however, comes from the scale of its traffic jams; spanning several islands as well as a large and expanding mainland area, the city never seemed to have enough bridges or arteries. The profusion of vehicles that came with the prosperity of the 1970s seemed often to be arranged in a massive standstill, which has become the site for urban peddling of an amazing variety of goods, as well as for entertainment, exasperation, innovation, and occasionally crime (Abiodun, 1997).

By 1990, Lagos had made some progress in managing its traffic problems both through road and bridge construction and traffic control regulations. This progress was aided by the economic downturn of the late 1980s, which ironically, facilitated urban - rural migration (Metz, 1991). However, it has been projected that by 2015, the population of Lagos in Nigeria will be around 24.3 million; thereby ranking it as the third largest city in the world. This trend of growth puts strain on the city where most resources will be consumed and this process thus constitutes a critical challenge to sustainability in Nigeria. (Adesina, 2003; Adegun, 2011). Aside from Lagos, other cities like Ibadan, Port Harcourt in the Niger Delta region, Kano and Calabar, also grew very rapidly as commercial and administrative centers in Nigeria. However, a dominant urban feature common to them is the degrading state of the physical environment. Unfortunately, the uncontrolled growth pattern associated with the urbanization process has been responsible for the diverse environmental problems in these cities (Fourchard, 2003; Jiboye, 2005). An immediate consequence of the rapid urbanization in these cities is the increase in demand for urban services like housing, education, public health and a generally decent living environment (Ogunleye, 2005).

Notably, a peculiar feature of urbanization in Africa is in its spontaneity (Jiboye, 2003; Daramola \& Ibem, 2011); and in Nigeria, available report indicates that urban population has been growing at an alarming rate of about 47 percent as at 2003 (UN, 2004; Ajala, 2005), while most of the major cities expand without incorporating the major element of physical planning. Until recently, Nigeria did not have any regulatory codes or standard to guide planning of building and environmental development (Adediran, 2007). Consequently, the forces of urbanization and industrialization have brought about changes in production activities, thus resulting in explosive demographic changes with growth rates ranging between $6 \%$ and $12 \%$ per annum. This rate of urban growth and the relative poverty that accompanies it poses a critical challenge to effective governance and sustainable development (Jiboye, 2005).

There is no doubt that Nigeria as a nation is experiencing rapid urbanization which has brought about various socio - economic, cultural and environmental problems, particularly, degradation of the physical urban environment which exists in the nature of loss of biodiversity and green-house warming, desertification, degradation of agricultural land, air and water pollution, environmental decay, slums, insanitation, overcrowding, housing congestion, crime and violence, and several other demeaning situations (Omisore et al., 2003; Ogunleye, 2005; Jiboye \& Omoniyi, 2010; Daramola \& Ibem, 2010). Considering the challenges posed by the diverse problems associated with urbanization and the need for sustainable development in Nigeria, urgent step is required on the part of government in particular and other stakeholders responsible for urban development, through effective governance to control the rate at which urban population and the spread of cities increases. Also, effort is required to control the decline in the quality of urban infrastructure as well as improve the overall standard of living of the people in Nigeria.

\subsection{The need for effective governance in sustainable urbanization in Nigeria.}

Development as a concept has different definitions. Citing Ake (1996), Nakpodia (2011) notes that development is not a project but a process. It is the process by which people create and recreate themselves and their 
circumstances to realize higher levels of civilization in accordance with their own choices and values. Therefore, development under the contemporary paradigm refers to a qualitative improvement in the standard of living of human beings rather than a quantitative increase in the economic indices; it is measured in terms relative to the individual's access to economic, social and environmental factors which are necessary to improve his standard of living. However, the ultimate challenge of sustainable development strategies is how to integrate all aspects of development - particularly within the socio-economic and environmental framework towards achieving "sustainability". Thus, a socially, economically or an environmentally sustainable system should achieve distributional equity; provide adequate social services including health, education, housing as well as functional and livable environment among many others (Jiboye, 2009; Jiboye \& Omoniyi, 2010).

The problems of slum formations and urban degeneration in Nigeria are common occurrence in major cities particularly, in Lagos and Ibadan which are probably among the largest cities in the country (Fourchard, 2003) (see Figures 1-6). Over the past decades, these problems have constituted major challenges to sustainable urban development. Official response to the situation through urban renewal, slum upgrading and outright clearance has been counter-productive in stimulating any form of sustainability. For instance, the effect of Maroko slum clearance in Lagos in the early 1990s has led to several untold hardships and consequent homelessness amongst most of the affected victims (Jiboye \& Ogunshakin, 1997; Abiodun, 1997). Therefore, the need to achieve sustainability of the cities' urban environment is central to the achievement of a virile and sustainable nation. However, existing urban realities have shown that a lot of work needs to be done if Nigeria is to achieve any sustainable development. Considering the extent of problems necessitated by rapid urban growth in Nigeria, there is the need for a radical approach towards achieving a desirable sustainability of the urban environment. This need centers on ensuring good and effective governance which seeks to employ sustainable development strategies entrenched in Agenda 21; to integrate all aspects of development socially, economically, culturally and environmentally in achieving distributional equity and providing adequate social services including health, education, housing as well as functional and livable environment among many others.

\section{Policy options: Towards sustainable urbanization in Nigeria.}

It has been argued that commitment to sustainable development both for the present and future generations will be meaningless if collaborative approach is not employed (Oyeshola et al., 2009). Thus, it would be beneficial to assert that the solution to the lingering urban problems in Nigeria does not reside in proffering new policies per-se, but in the determination of all those involved in formulating and implementing urban policies to address the problems of growth in cities. However, one of the major threats to sustainable urban growth in Nigeria is poverty. In Nigeria, poverty is defined as a state of long-term deprivation of well-being, a situation considered inadequate for a decent life. It is synonymous with lack and is also a long-term phenomenon (Fourchard, 2003). A World Bank data has revealed that 60 percent of Nigerians live below the poverty line, only 50 per cent of the population has access to safe water, and about 38 per cent do not have access to primary health care (World Bank, 1996). Thus, poverty jeopardizes the political stability, social cohesion and environmental balance of our cities, and until it is tackled decisively, sustainable development will remain a mirage (Olanrewaju, 2003).

The explosive rates of growth have not only progressively complicated and exacerbated inter-related problems of human settlements and environment, but have also greatly accelerated poverty (Oladunjoye, 2005). The issue of poverty needs to radically examined and accorded all the attention it deserves if achieving sustainability is anything to go by. The need to ensure sustainability in our cities is imperative and this depends largely on the application of the principle of sustainable development advocated by the Commission on Environment and Development - whereby, developmental efforts should not only concentrate on solving present problems but also consider future challenges and needs.

As part of efforts along this direction, the United Nations Centre for Human Settlements (UN-Habitat) and UNEP while responding to the complex environmental problems facing the nations launched the Sustainable Cities Programs which aimed at providing municipal planning and management capacity (Monghtin, 2003). This led to the 2005 Global Meeting of the Sustainable Cities Programme (SCP) and Localizing Agenda 21Programme (LA21) Partners which took place in La Havana, Cuba. The theme of the meeting is "Achieving sustainable urbanization - Innovations for local and global results" with a focus on mainstreaming and institutionalization of the Environmental Planning and Management (EPM) concept. Other similar initiative includes the New Partnership for African Development (NEPAD) Programme; in which seven African cities were selected. Ibadan, Enugu and Lagos are three major Nigerian cities which benefited from the start of these programmes (Oladunjoye, 2005; Daramola \& Ibem, 2010). Thus, in the last five years, Nigeria through its counterpart development initiative - National Economic Empowerment and Development Strategies (NEEDS), has been pursuing an integrated approach in the planning and management of its rapid urbanization which has 
resulted in reviews of the national policies on Urban Development and Housing. The central focus of the strategy is on poverty reduction, alongside sectoral policies on environmental management, sanitation, water, health and population. Issues of good governance and improved popular participation in governance and partnership with national and international development partners are also being mainstreamed into national agenda for development (Oladunjoye, 2005).

Although, these initiatives and programmes appear potent, dynamic and desirable forces for development; for them to produce the desired impact in Nigeria, they must adopt strategies that would make significant impact on problems and issues relating to urbanization, attitudinal orientation and lapses in the legal and institutional frameworks in urban environmental management. So far, the impact of such programs on most cities in Nigeria is yet to be fully realized.

Based on this, specific policy issues and strategies should be considered. These are discussed under three main heads: good governance, urban regeneration and enhanced infrastructural development as well as improved collaborative role of the African Forum and other stakeholders.

\subsection{Ensuring good and effective Governance}

Central to the issue of achieving sustainable urban growth is the need for good governance. This should be in accordance with the principles entrenched in the United Nations global Agenda 21; which seek to employ sustainable development strategies to integrate all aspects of development socially, economically, culturally and environmentally in achieving distributional equity and providing adequate social services including health, education, housing as well as functional and livable environment among many others. However, one peculiar feature of governance in Nigeria is the use of Top-down approach to policy formulation and implementation. Consequently, policies and programmes emanating from such approach have continually rubbed the urban poor of their dignity (Onakuse \& Lenihan, 2007). Therefore, any worthwhile institutional approach in governance must consider among others: greater involvement of NGOs and community groups in local governance, greater transparency and accountability in both planning and implementation of local policy and the devolution of responsibility for urban affairs from state or national level to the local level. These are inevitable as the problems of urbanization can only be dealt with in an atmosphere of peace, better leadership (devoid of corruption) and freedom, especially in a politically frayed and frazzled continent as Africa. And as a major characteristic of good urban governance; decentralization of power, authority and responsibilities aids effectiveness as well as reaching out to the grassroots (Adegun, 2011).

This idea falls in line with the Millennium Development Goals (MDGs) which places premium on the role of local government as primary agents of change. However, devolution of power should not be equated with redundancy or abdication of vision and responsibility by any tier particularly the higher authorities. The efficiency of the decentralized system can only come with clear visioning, supervision, mentoring, and joint sharing of resources as well as capacity building by the tiers of government. Essentially, government policies should be based on the real needs of the people and not informed by mere speculations and selfish political reasons.

\subsection{Urban Regeneration and Enhanced Infrastructural Development}

As the population of an urban centre increases, its need for infrastructure such as transportation, water, sewage and facilities such as housing, commerce, health, schools, recreation and others increases (Ujoh et al., 2010); therefore, increasing the environmental carrying capacity of the urban areas is necessary for enhancing the livability of cities in Nigeria. Massive rehabilitation and expansion of urban infrastructure in the country should be taken more seriously. Most of the urban centres require extensive regeneration and upgrading programs. This would improve living condition as well as posit it against the culminating effect of urbanization. Considering the case of Maroko evacuation experience in Nigeria (Jiboye \& Ogunshakin, 1997), involuntary resettlement has been proved not to be the best option in urban renewal programs. It should only be subscribed to as a solution of the last resort and clearly justified.

To arrest rapid rate of urbanization due to rural-urban drift, there is need to integrate rural development plans into the national strategies in order to bridge the wide gap between the urban and rural areas in terms of job opportunity and availability of basic infrastructure. Equitable urban land use and management systems, sustainable agricultural policies are also very imperative in this regard. However, it has been observed that across the globe, urban rehabilitation and housing development strategies are shifting towards participatory approaches, especially public-private partnerships. The potential of this approach to deliver both low-income and market-rate housing units must be explored (Adegun, 2011). Government on its part should ensure that adequate funds are allocated for shelter provision to the vulnerable group of the urban population. Housing finance 
policies should integrate the lower-income group by providing easy access to long-term housing loans with sustainable interest. Disbursement of such loans should be done through recognized Cooperative Unions or community groups in order to encourage self-help housing delivery.

\subsection{Improved collaborative role of the African Forum}

There is a need for collaborative efforts by all governmental Agencies at regional, national and local levels towards ensuring good governance and sustainable urban development. The New Partnership for Africa's Development (NEPAD) is an initiative for speeding up sustainable development in Africa. Other counterpart initiatives like NEEDS and SEEDS which operate at the national and state levels in Nigeria should collaborate to ensure speedy actualization of the UN Global Agenda 21 and Goal 7 of the MDGs Agenda on the sustainability of cities. The African Ministerial Conference on Housing and Urban Development (AMCHUD); a body of ministers responsible for housing and urban development in Africa (Oladunjoye, 2005; Okunola, 2010; Daramola \& Ibem, 2010; Adegun, 2011), has a key role to play in facilitating these initiatives. Reactivating and formalizing the relationship between the AU and AMCHUD with a view to strengthening it as a forum for addressing the challenges of urbanization, urban governance, land management and shelter in Africa is highly imperative. The duo's role at emerging a bright future for the African cities would definitely include; making the issue of urban poverty and the concept of sustainable cities a top priority on national and international agenda. This would also include implementation of the various charter and plans of action, the promotion of NEPAD Cities as engines for growth and tools for regional and international integration among many other collaborative roles (Adegun, 2011).

Above all, there is the need for government and stakeholders - including professionals involved in urban development planning to imbibe the right political will and commitment while formulating and implementing its programs. Essentially, planning strategy for housing, infrastructural provision and urban management must make the people its focus.

\section{Conclusion}

This paper has examined the need for effective governance in the realization of sustainable urbanization in Nigeria. The paper notes that Urbanization is a global issue and an inevitable phenomenon in Nigeria. It observes that the pervasiveness and spontaneity associated with the urban growth process in Nigeria has been an issue of concern; as it essentially constitutes serious socio-economic, cultural and environmental challenges to the attainment of sustainable development and effective urban governance. This problem of spontaneous urban growth has been necessitated by the features of globalization, industrialization and population explosion, with its attendant challenges of uncontrolled growth of cities, which has led to a degraded environment and poor living standard of the people. Considering that growth within the context of urbanization should be guided towards improving the environment rather than harming it (Newman, 2002; Jiboye, 2009); this growth according to the concept of "sustainable development" must be sustainable in order to take care of the present needs without compromising the ability of future generation to meet its own needs. This according to William et al. (2002) could be achieved through forms of governing that are empowering and also sensitive to the needs of future generations. Thus, a participatory, multi-stakeholders' and collaborative approach to policy-making and implementation has been advocated as key requirements to achieving an ideal sustainability (Desai, 2002; Mabogunje \& Robert, 2004; Gille, 2011). This essentially is the main concern which good and effective governance should promote towards stimulating sustainable growth and secure a qualitative environment that is conducive for the well-being of all Nigerians.

\section{References}

Abiodun, J. O. (1997). "The challenges of growth and development in Metropolitan Lagos". In, C. Rakodi (Ed). The Urban challenge in Africa. Growth and Management of its large Cities. UN University Press. NY. 153-176. [Online] Available: http;//www.unu.edu/unupress/unupbooks/ unu26ue/uu26ue0i.htm6. (March 27, 2009).

Adedeji, Y. M. D. (2005). "Sustainable Low- Cost Housing Technology in Cities: Accelerated Construction Initiative Option" Journal of Land Use and Development Studies. 1 (1), 10.

Adediran, A. (2007). Challenges of the new national building Code. Presented at the continuing professional development program. By, NITP and TOPREC. Lagos, Nigeria. July - August.

Adegun, O. B. (2011). Shelter and the future African city. The Built \& Human Environment Review. 4 (2), $33-40$. 
Adesina, A. O. (2003). Legibility and the Nigerian Urban Environment. Experiences from Ilorin: In, V. Adekunle et al. (Eds.). Proceedings of the Conference on the Challenges of environmental sustainability in a democratic governance. Environment and Behaviour Association of Nigeria. Lagos, Nigeria.

Ajala, O. A. (2005). "Environmental Impact of Urbanization: The challenges to urban governance in Nigeria". In, W. Fadare, et al. (Eds.). Proceedings of the Conference on Globalization, Culture and the Nigerian Built Environment. Vol. II. Obafemi Awolowo University, Ile-Ife, Nigeria.

Ajanlekoko, J. S. (2001). "Sustainable housing development in Nigeria - The financial and infrastructural implication". International Conference on Spatial Information for Sustainable Development. Nairobi, Kenya. [Online] Available: www.fig.net/pub/proceedings/nairobi/ajanlekoko - CMWS 1.pdf. (March 27, 2009).

Ake, C. (1996) Democracy and Development in Africa, USA. Brookings Institute.

Aluko, O. (2010). Rule of law, planning and sustainable development in Nigeria. Journal of Sustainable Development in Africa. 12 (7), 88-95.

Brockerhoff, M. (2000). An Urbanizing World. Population Bulletin of Population References Bureau, United Nations. 55 (3).

Daramola, A. \& Ibem, E. O. (2010) Urban Environmental Problems in Nigeria: Implications for Sustainable Development. Journal of Sustainable Development in Africa. 12 (1), 124-144.

Desai, N. (2002). Johannesburg and Beyond. Making Sustainable Development a Global Reality. Global challenge, Global opportunity: Trends in sustainable development. United Nations department of economic and social affairs for the World summit on sustainable development. Johannesburg, 26 August - 4 September, 2002. [Online] Available: www.johannesburgsummit.org. (March 27, 2009).

European Environment Agency (2006). Urban sprawl in Europe - The ignored challenge. EEA Report No. 10/2006._pdf. (August 6, 2011)

Federal Republic of Nigeria (FRN) (2007). Official Gazette on the breakdown of the National and State Provisional Totals 2006 census, S.I No. 23 of 2007, 94 (24), Lagos.

Fourchard, L. (2003). Urban Slums Reports: The case of Ibadan, Nigeria. Understanding Slums: Case Studies for the Global Report on Human Settlements. Institut Francais de Recherche en Afrique (IFRA), University of Ibadan, Nigeria. [Online] Available: http//www.ucl.ac.ukdpu projectsGlobal_ReportpdfsIbadan.pdfIbadan (July, 2011).

Gille, A. (2011). City Development Strategies in the City of Kampala. An analysis of participatory development in practice. Department of Physical Geography and Ecosystem Analysis University of Lund, Sölvegatan 12223 62 Lund, Sweden. [Online] Available: http/www. gille_anneli sustainable development in Kampala. pdf-adobe reader. (July 19, 2011).

Jiboye, A. D. (2003). Urbanization and the urban growth process. Strategies for renewal. In, V. Adekunle, et al. (Eds.). Proceedings of the Conference on, the Challenges of environmental sustainability in democratic governance. Environment and Behaviour Association of Nigeria.

Jiboye A. D. (2005). "Globalization and the Urban growth process in Nigeria". In, W. Fadare et al. (Eds.). Proceedings of the Conference on Globalization, Culture and the Nigerian Built Environment. Vol. II. Obafemi Awolowo University, Ile-Ife, Nigeria.

Jiboye, A. D. (2009) The challenges of sustainable housing and urban development in Nigeria. Journal of Environmental Research and Policies. 4 (3), 23-27.

Jiboye, A. D. (2011a) Shelter for the Urban Homeless: The Challenge for Sustainable Cities' development in Nigeria. The Built \& Human Environment Review. 4 (2), 14-21.

Jiboye, A. D. (2011b) Achieving Sustainable Housing Development in Nigeria: A Critical Challenge to Governance. International Journal of Humanities and Social Science. 1 (9), 121-127.

Jiboye, A. D. (2011c) Ensuring Sustainable Development through an Effective Housing Delivery Process in Nigeria. African Journal of Social Sciences. 1 (2), 36- 45.

Jiboye, A. D. \& Omoniyi, S. S. (2010). Environmental Sustainability and urban growth in Nigeria. Journal of Environmental Research and Policies. 5 (1), 43-50.

Jiboye, A. \& Ogunshakin. (1997). "The death of the house: The Maroko Experiences". In, B. Amole (Ed). The house in Nigeria. Obafemi Awolowo University, Ile-Ife, Nigeria. 
Lawanson, T. O. (2005) Challenges of Sustainability and Urban Development in Nigeria: Reviewing the Millennium Development Goals. In, W. Fadare, et al. (Eds). Globalization, Culture and the Nigerian Built Environment. Vol. II. Obafemi Awolowo University, Ile-Ife, Nigeria.

Mabogunje, A. (1985). Towards an urban policy in Nigeria. In, P. Onobokun. (Ed.). Housing in Nigeria. A book of readings. Ibadan, Nigeria. NISER.

Mabogunje, A. L. \& Robert, W. K. (2004). Sustainable Development in Ijebu-Ode, Nigeria: The Role of Social Capital, Participation, and Science and Technology. CID Working Paper No. 102, Cambridge, MA: Sustainable Development Program, Center for International Development, Harvard University. [Online] Available: http://www.cid.harvard.edu/cidwp/102.htm (July 19, 2011).

McCarney, R., Halfani, M. \& Rodriquez, A. (1995). Towards an Understanding of Governance: The Emergence of an idea and its implications for Urban research in Developing countries in Urban Research in the Developing World (Vol. 4): In, R. Stren and J. Bell (Eds.). Perspectives on the City (pp 91-141). Toronto. Centre for Urban and Community studies, University of Toronto.

MediaWiki. (2008). Understanding development: Taking I.T Global. [Online] Available: http://www. wiki.tigweb.org. (March 27, 2009).

Metz, H. C. (ed.) (1991). "Nigeria - Urbanization since independence". A country study. Washington. G.P.O for the Library of Congress. [Online] Available: http://www.countrystudies.us/nigeria/ (December 15, 2009).

Monghtin, C. (2003). An Urbanizing World. Global report on human settlements 1196. Hague, Belfast.

Nakpodia, E. D. (2011) Philosophy as a tool for Sustainable Development: A Contemporary Issue in Nigerian Educational System. African Journal of Social Sciences. 1 (1), 65 - 74.

National Academy of Sciences (2003). Cities Transformed: Demographic Change and its implications in the Developing World. In, M. R. Montgomery et al. (Eds). Panel on Urban Population Dynamics. National Research Council. London. Earthscan.

National Affordable Housing Association (NAHA. 2006. Sustainability; Policy Areas. [Online] Available: http;//www.housingcorp. gov. uk. (March 27, 2009).

Newman, P. (2002). Sustainability and Planning: A whole government approach. An oration Text. Barnet, Melbourne.

Oduwaye, A. (2009). Challenges of Sustainable Physical Planning and Development in Metropolitan Lagos. Journal of Sustainable Development. 2 (1), 159-171.

Ogunleye B. (2005). "Environmental degradation control for sustainable urban growth in Nigeria" In, W. Fadare, et al. (Eds.).Proceedings of the Conference on Globalization, Culture and the Nigerian Built Environment. Vol. II. Obafemi Awolowo University, Ile-Ife, Nigeria.

Okunola, P. (2010). Africa Ministers adopt Fresh Charter to Manage Soaring City Growth. The Guardian Newspapers. (Monday, 29 November. pp.31).

Oladunjoye, A. O. (2005). Nigeria: Implementation of the Sustainable Cities Programme in Nigeria. Sustainable Cities Programme. Localizing Agenda 21 Programme. United Nations Programme for Human Settlements. (UN-HABITAT).United Nations Environment Programme (UNEP). Havana, Cuba. [Online] Available: www.unhabitat.org/scp - http://ww w.unhabitat.org/la21. (September 30, 2010).

Olanrewaju, D. O. (2003). "Sustainable environment and the poor. A keynote Address". In, V. Adekunle, et al. (Eds.). Proceedings of the Conference on the Challenges of environmental sustainability in democratic governance. Environment and Behaviour Association of Nigeria. Lagos, Nigeria.

Omisore E. O. \& Akande C. G. (2003). "The roles of all tiers of government and non-governm ental organizations (NGOs), in environmental conservation", In, V. Adekunle et al. (Eds.). Proceedings of the Conference on the Challenges of environmental sustainability in a democratic governance. Environment and Behaviour Association of Nigeria. Lagos, Nigeria

Onakuse, S. \& Lenihan, E. (2007). Policies, Programmes, and Sustainable Development in Nigeria: A Critique. Africana. 1 (1). 42-58.

Osasona C., Ogunshakin L. \& Jiboye A. (2007). “The African Woman's right to security Through sanitation. From the dwelling unit to the neighbourhood". Conference proceeding on, Right to Live in Africa. Trieste, 9 - 10 November. University of Trieste, Italy. 
Oyeshola, O. P. D., Ajayi, Y. \& Jiboye, T. F. (2009). "Teaching International Relations: Techniques, Approaches, Priorities and Challenges". Legon Journal of International Affairs (LEJIA). 6 (1). 62-76.

Padisson, R. (Ed.) (2001). Hand Book of Urban Studies. London. Sage Publications.

Ravallin, M. 2007. “Urban poverty”. Journal of Finance and Development. 15-17.

Ujoh, F. Kwabe, I. D. \& Ifatimehin, O. O. (2010). Understanding urban sprawl in the Federal Capital City, Abuja: towards sustainable urbanization in Nigeria. Journal of Geography and Regional Planning. 3 (5). 106-113. [Online] Available: http://www.academicjournals.org/JGRP (July 19, 2011).

United Nations (2002). World Population Prospects: The 2001 Revision. Data Tables and Highlights. United Nations. Department of Economic and Social Affairs. Population Division. New York.

United Nations. (2004). World population policies 2003. New York. USA. United Nations.

United Nations, (2007). Achieving the Millennium Development Goals in Nigeria. How Far Now? UN-Habitat' United Nations Week. Abuja, Nigeria.

UNCHS, (1996). An Urbanizing World: Global Report on Human Settlements. Oxford. Oxford University Press.

UNCHS (2007). Urbanization: A Turning Point in History. Global Report on Urbanization [Online] Available: www.unhabitat.org. (March 27, 2009).

UNDP. (1997). Governance for Sustainable Human Development. New York. United Nations Development Programme.

United Nations Department of Public Information (UNDPI). (2008). Achieving the Millennium Development Goals in Africa. Recommendations of the MDG Steering Group. [Online] Available: http;//www.mdgafrica.org. pdf. (March 27, 2009).

UNFPA (2007). State of the World Population 2007, Unleashing the Potential of Urban Growth. New York. United Nations Population Fund.

UN-HABITAT, (2004). Urban Governance Index Conceptual Foundation and Field Test Report. Global Campaign on Urban Governance Global Urban Observatory. August 2004. United Nations HABITAT. Nairobi.

UN-Habitat, (2007). Milestones in the evolution of human settlements policies.1976-2006. State of the world cities. Report 2006/2007. The MDGs and urban sustainability. 30years of shaping the Habitat Agenda. U.K. Earthscan.

United Nations Human Settlement Programme (2010). The State of African Cities. Governance, Inequality and Urban Land Markets. United Nations HABITAT. Nairobi.

WCED, (1987). Our Common Future. World Commission on Environment and Development. Oxford University Press. Oxford, New York.

William C. Clark. 2002. Science and Technology for Sustainable Development: Initiative on Science and Technology for Sustainability. Consensus Report of the Mexico City Synthesis Workshop, May, 20-23, 2002. Cambridge, M. A. [Online] Available: http://sustainabilityscience.org/ists (July 19, 2011).

World Bank. (1995). Defining an environmental development strategy for the Niger Delta, Nigeria. World Bank Report 14266.

World Bank. (1996). Poverty in the Midst of Plenty: The Challenge of Growth with Inclusion. Report no. 14733, Washington D.C. 
Table 1. Population, Urban Population and Growth rate in Africa

\begin{tabular}{c|c|c|c}
\hline Year & $\begin{array}{c}\text { Population } \\
\text { (thousands) }\end{array}$ & $\begin{array}{c}\text { Urban population } \\
\text { (thousands) }\end{array}$ & $\begin{array}{c}\text { Average annual urban } \\
\text { growth (percentage) }\end{array}$ \\
\hline 1990 & 518,053 & 146,673 & - \\
1995 & 593,183 & 181,582 & 3.79 \\
2000 & 674,842 & 220,606 & 3.44 \\
2005 & 764,328 & 266,935 & 3.40 \\
2010 & 863,314 & 321,400 & 3.36 \\
2015 & 970,173 & 384,696 & 3.28 \\
2020 & $1,081,114$ & 456,580 & 3.14 \\
2025 & $1,193,752$ & 537,128 & 2.98 \\
2030 & $1,5000,000$ & $787,000,000$ & 2.10 \\
\hline
\end{tabular}

Source: UN-HABITAT, 2010 (Updated from Adegun, 2011).

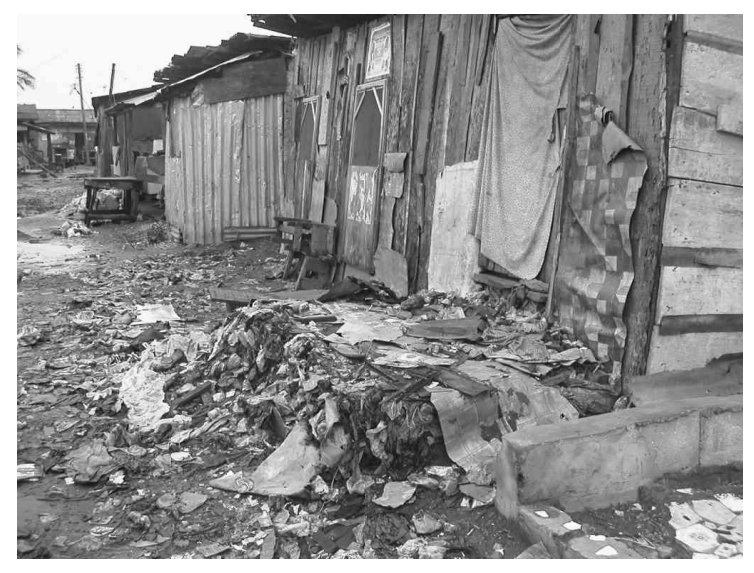

Figure 1. Unsightly living condition in Ajegunle, a core urban area in Lagos

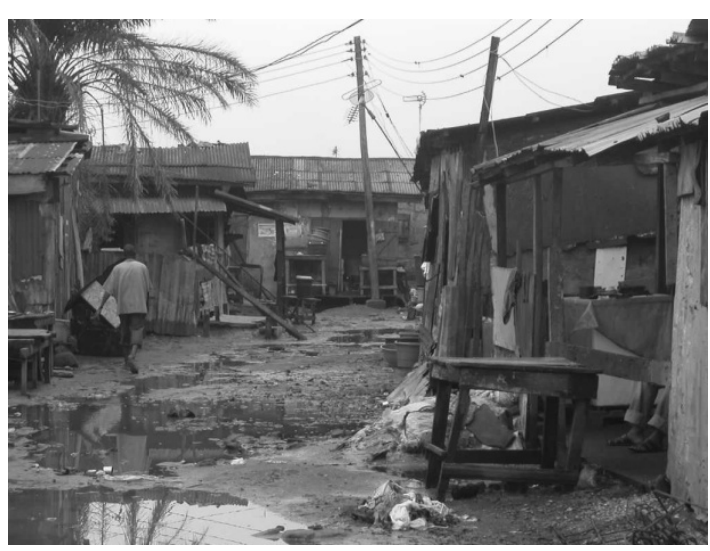

Figure 2. A degraded neighbourhood in Lagos Nigeria (foreground waterlogged) 


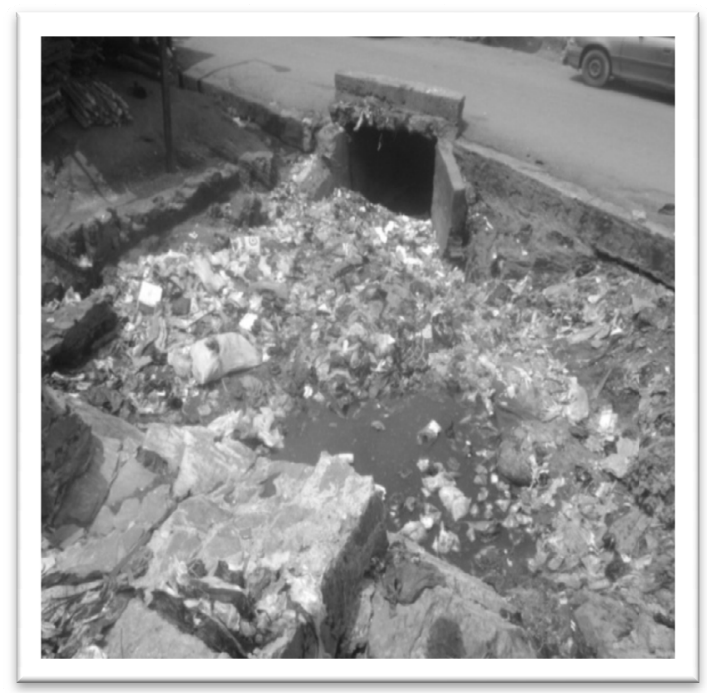

Figure 3. Core urban area in Ibadan. (drainage tunnel blocked by refuse disposed indiscriminately in Beere-an effect of the poor refuse management in the urban area)

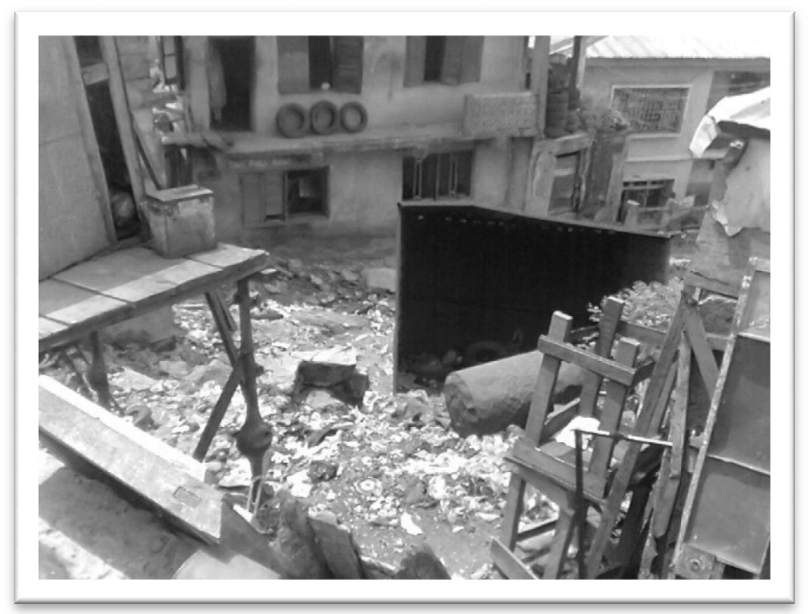

Figure 4. A decaying housing environment (Un-kept and degraded living environment, unsuitable for residents decent living)

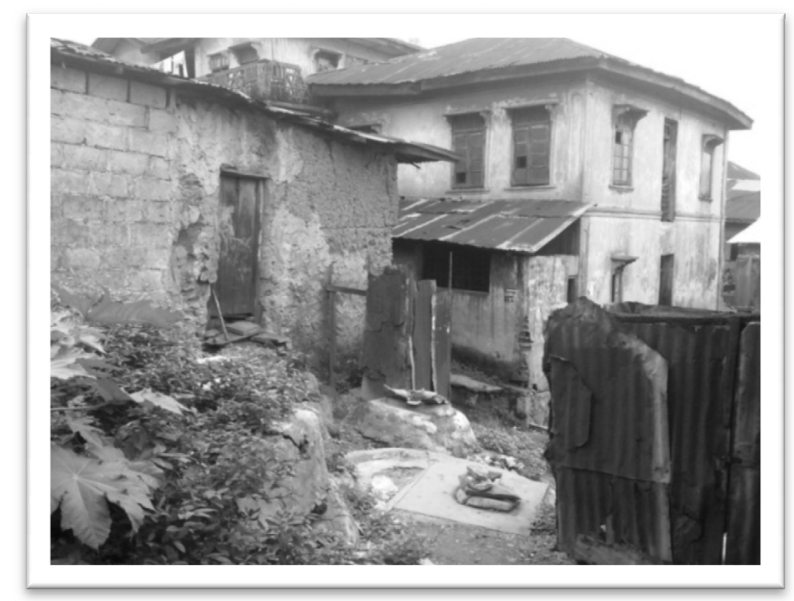

Figure 5. A derelict housing situation in Ibadan (with externalized corrugated sheets bathroom) 


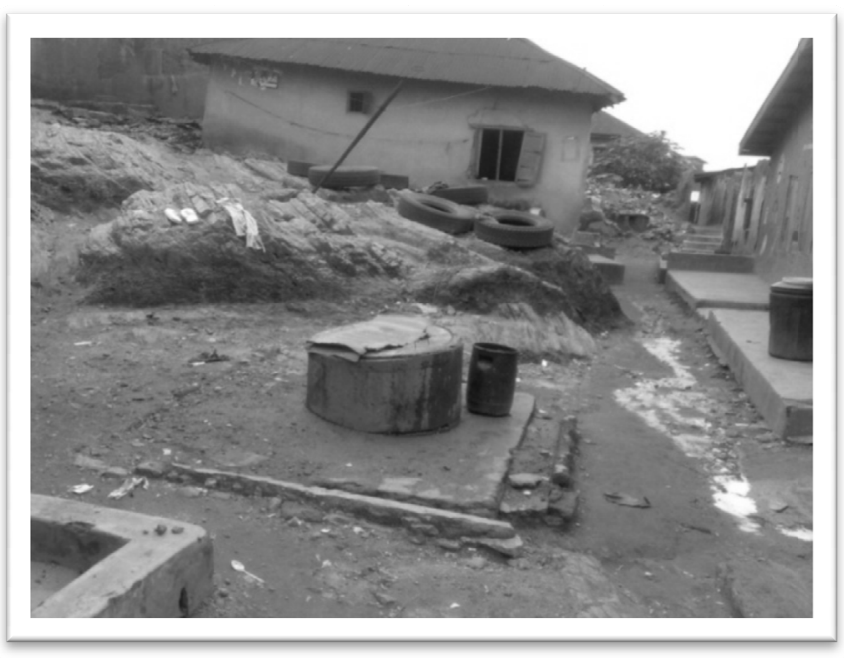

Figure 6. A public water source in Oja-oba area, Ibadan. (Available source of water for inhabitants of the community, un- kept and prone to waterborne diseases)

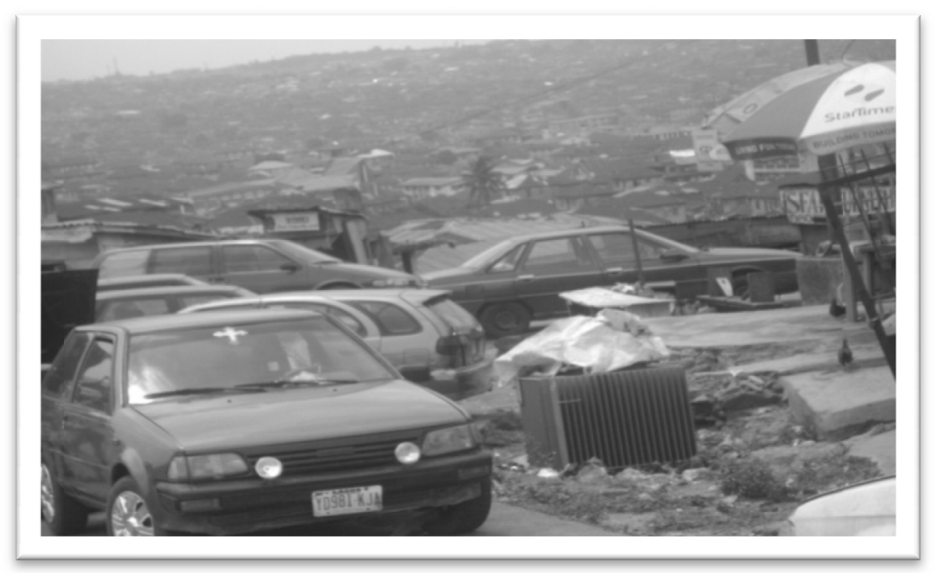

Figure 7. A chaotic traffic situation in the core urban area of Ibadan 